\title{
Radiation Dose and Risk in Dental Panoramic Radiography: literature review
}

\author{
Naoual Elmorabit ${ }^{1, *}$ and Oum Keltoum Ennibi ${ }^{2}$ \\ ${ }^{1}$ Laboratoty of Research on Oral Biology and Biotechnology, Faculty of Dental Medicine, Mohammed V University in Rabat, Morocco \\ ${ }^{2}$ Laboratoty of Research on Oral Biology and Biotechnology, Faculty of Dental Medicine, Mohammed V University in Rabat, Morocco
}

\begin{abstract}
- Abstract. Aim: To review and search studies that evaluated the radiation doses and risks from dental panoramic radiography (DPR). This review may answer the following question "does panoramic dental radiation expose patients to health risks? Materiels and Methods: The search strategy was performed using the databases including GoogleScholar, PubMed, Science Direct and Nature from 2010 until september 2020. The search was limited to articles published in English. The 1031 titles that appeared, 15 fulfilled the criteria and were included in the review. Results: in 10 studies, the effective dose from DPRs was in the range of $5-49 \mu \mathrm{Sv}$, depending on the panoramic equipment used. The salivary glands received the highest absorbed doses (359-3044,3 $\mu \mathrm{Gy})$ and the thyroid gland absorbed doses were (40-250 $\mu \mathrm{Gy})$. In terms of health risk, according to 5 studies, DPRs can induce genotoxic effects in oral epithelial cells and even induce cytotoxic effects leading to cell death. In 2 studies, women are at higher risk than men. The overall risk of cancer from radiation in children was more than adult. Conclusion: DPR can expose patient to health risks. It should only be applied when necessary, using radiation protection criteria.
\end{abstract}

\section{Introduction}

Dental panoramic radiography (DPR) - also known as orhopantomography - is the extraoral technique the most often used in dentistry[1], [2]. The DPR is a modified type of tomography, which provides a two-dimensional (2D) and broad anatomical view of the teeth, maxilla, mandible, temporomandibular joints, and relevant facial structures on a single image[3]

During DPR, the X-ray beam passes through salivary glands, oral mucosa, and part of orbits[4]. Depending on the anatomy, size, and positioning of the patient, as well as on the image-field size, the thyroid gland and the eyes may also become irradiated[5].

Although the radiation dose received during DPR is low, the cumulative effect of small doses on sensitive tissues could induce both gene mutations and chromosomal aberrations. X-rays act directly on the DNA molecule or indirectly through the formation of reactive compounds that interact with this molecule[6], [7].

It is a fundamental requirement of radiation protection that all exposures to $\mathrm{x}$-rays as part of diagnosis should be clinically justified for each patient[8]. Prescription of dental radiographic examination is made on individual basis, needs justification and optimization according to international recommendations [9]. Thus, it is not justified to take DPR before a clinical examination, for all new patients and to screen asymptomatic patients[10]. However, a questionnaire study, found that $42 \%$ of dentists with panoramic x-ray equipment carried out routine panoramic radiography of all new adult patients[11]. Moreover, a recent study indicates that approximately one fourth of the DPRs lacked an adequate referral[12].
When panoramic radiography was indiscriminately used, resultant yield was negligible or extremely low for most of the patients[11].

This study aimed to review previous research which evaluated the radiation doses and risks from dental panoramic radiographies.

This review may answer the following question "does panoramic dental radiation expose patients to health risks?

\section{Materials and Methods}

The search strategy was performed using the databases including GoogleScholar, PubMed, Science Direct and Nature from 2010 untilseptember2020; using the key words: "dental panoramic radiography and radiation risks", "panoramic radiography and radiation doses" and "panoramic radiography or orthopantomography and radiation risks". The search was limited to articles published in English. Abstracts were reviewed and relevant papers were identified.

Inclusion criteria: Included studies on otherwise healthy subjects, studies on radiation risk of panoramic radiography in humans, both genders and / or children, and studies reporting absorbed doses by organs. Both film and digital radiography methods were considered. Exclusion criteria: were studies on intra-oral radiographs, and 3D radiography. Studies including patients suffering from a malignant disease were excluded too.

\footnotetext{
*Correspondence:: nawal.elmorabit@gmail.com

Department of Odontological Sciences, Laboratoty of Research on Oral Biology and Biotechnology, Faculty of Dental Medicine, Mohammed V University in Rabat, Morocco
} 


\section{Results}

Totally 1031 relevant articles were identified through the literature search, some of these studies did not involve radiation risk or dose from DPR. Fifteen (15) articles fulfilled the criteria and were included in the review.

For the literature review, this study examined fifteen papers on DPR exposure doses and health effects. Among fifteen papers that reported a dosimetry of DPR and overall risks, ten papers assessed the effective doses and organ-absorbed doses from DPR and seven papers related to radiation health risks from DPR.

These studies were conducted in the following countries: Sweden $(n=2)$, India $(n=4)$, Iran $(n=4)$, china $(n=1)$, Taiwan $(n=3)$, Brazil $(n=1)$.

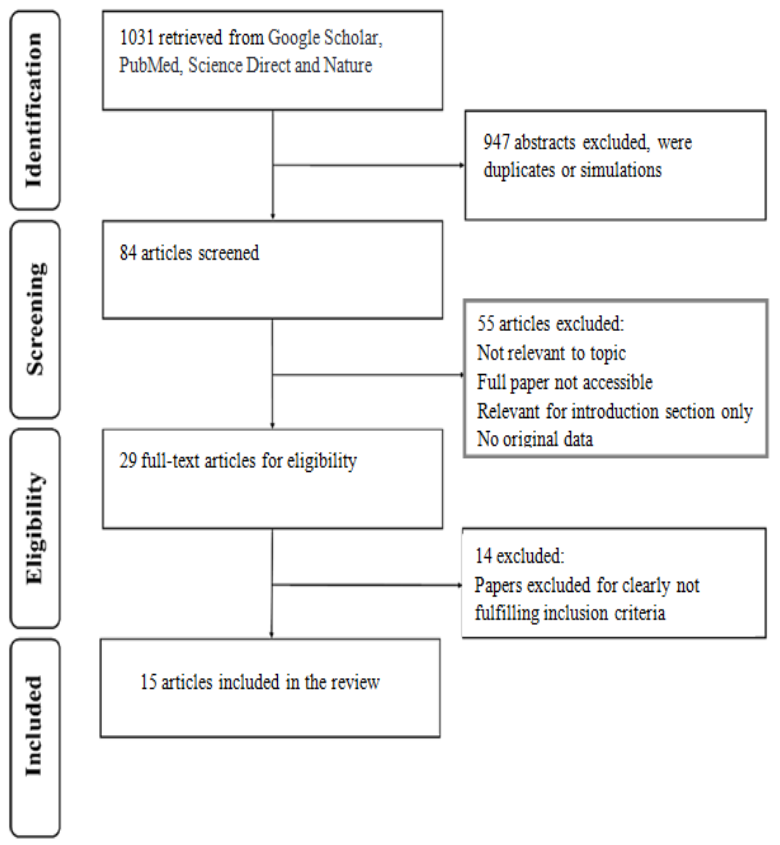

Fig. 1. Flow diagram of study selection

According to 6 studies, the effective dose for DPR was in the range of $5-49 \mu \mathrm{Sv}$ Table 1. The mean of effective radiation dose generated by the panoramic radiography accordingly to selected studies was $22,16 \pm 15,66$

Table 1. Effective doses ( $\mu \mathrm{Sv}$ ) during a Dental Panoramic Radiation (DPR)

\begin{tabular}{lllll}
\hline author (year) & & country & $\begin{array}{l}\text { Effective } \\
(\mu \mathrm{Sv})\end{array}$ & dose \\
\hline $\begin{array}{l}\text { Granlund and } \\
(2016)[13]\end{array}$ & al. & Sweden & $22-49$ \\
$\begin{array}{l}\text { Pai and al.(2012)[14] } \\
\text { Benchimol and al. }\end{array}$ & Sweden & $5-14$ \\
$\begin{array}{l}(2018)[9] \\
\text { Chaparian and }\end{array}$ & al. & Iran & 5,04 \\
$\begin{array}{l}(2017)[15] \\
\text { Qiang and }\end{array}$ & al. & china & 13 \\
$\begin{array}{l}(2019)[16] \\
\text { Lee and } \\
(2013)[17]\end{array}$ & al. & Taiwan & $8,9-37,8$ \\
Mean \pm s.d & & & 22,16 \\
& & & $\pm 15,66$ \\
\hline
\end{tabular}

According to 7 studies the values of absorbed doses from dental panoramic radiography in salivary and thyroid glands are presented in Table 2.

Table 2. Organ-absorbed doses ( $\mu \mathrm{Gy})$ during a Dental Panoramic Radiation (DPR)

\begin{tabular}{|c|c|c|c|}
\hline $\begin{array}{l}\text { author } \\
\text { (year) }\end{array}$ & country & $\begin{array}{l}\text { salivry gland } \\
\text { absorbed } \\
\text { doses }(\mu \mathrm{Gy})\end{array}$ & $\begin{array}{l}\text { Thyroid } \\
\text { gland } \\
\text { absorbed } \\
\text { doses }(\mu \mathrm{Gy})\end{array}$ \\
\hline $\begin{array}{l}\text { Granlund } \\
\text { and al. } \\
(2016)[13]\end{array}$ & Sweden & $939-2428$ & $48-111$ \\
\hline $\begin{array}{l}\text { Benchimol } \\
\text { and al. } \\
(2018)[9]\end{array}$ & Sweden & 89 & 40 \\
\hline $\begin{array}{l}\text { Campillo- } \\
\text { Rivera and } \\
\text { al. } \\
(2019)[18]\end{array}$ & Mexico & 3044,3 & 94,7 \\
\hline $\begin{array}{l}\text { Moudi and } \\
\text { al. } \\
(2013)[19]\end{array}$ & Iran & 230 & 130 \\
\hline $\begin{array}{l}\text { Naserpour } \\
\text { and al. } \\
(2019)[3]\end{array}$ & Iran & $160-558$ & $72-56$ \\
\hline $\begin{array}{l}\text { Toossi and } \\
\text { al. } \\
(2012)[20]\end{array}$ & Iran & 343 & 38 \\
\hline $\begin{array}{l}\text { Qiang and } \\
\text { al. } \\
(2019)[16]\end{array}$ & china & 622 & 256 \\
\hline
\end{tabular}

In terms of health effects, five studies treated the radiation risks and effects related to DPR. Table 3.

Among these eighteen papers, nine studies have issued recommendations to reduce radiation doses and risks from DPR, Table 4.

Table 3: Radiation risks from Dental Panoramic Radiation (DPR)

Risks Author (year) Country

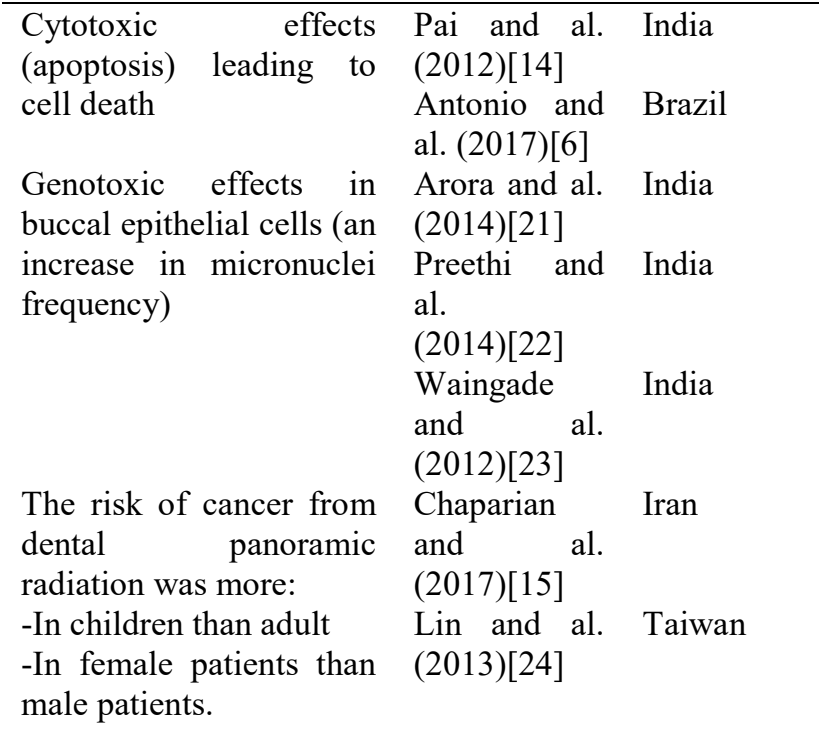




\section{Discussion}

It is accepted that X-ray exposure involves a risk, so it is essential that any X-ray examination should show a potential net benefit to the patient, weighing the total diagnostic benefits it produces against the detriment that the exposure might cause[25] . Even if the radiation dose is low in dental panoramic radiography, efforts to apply it carefully and to reduce the dose are essentials for patients.[17]

Therefore, it is important to analyze the effective dose, organ-absorbed dose of X-rays and to examinehealth risks in DPR.

For the literature review, this study evaluated fifteen papers on DPR exposure doses and health risks.

According to 6articles, the effective dose was in the range of $5-49 \mu \mathrm{Sv}$ (mean effective dose was $22,16 \pm 15,66)$, depending on the panoramic equipment and exposure parameters used.

The salivary and thyroid glands are among the organs at risk in dental radiology[13].

According to 7 studies, the salivary and the thyroid glands absorbed doses from panoramic radiography were in the range of 359-3044,3 $\mu \mathrm{Gy}$ and 38-256 $\mu \mathrm{Gy}$ respectively. This discrepancy maybe due to the variation in the patients' size, exposure parameters, number, location, and type of thermoluminescent dosimeters (TLDs), as well as the panoramic units used in these studies[3]. The size of the exposed area is one of the most important parameters that influence the patient dose[26].

In DPR there is a difference in absorbed dose depending on the area. The dose received by thyroid gland, mainly due to scattered radiation, is comparably less than the dose received by the salivary Glands[20]. There is no evidence that absorbed dose from panoramic imaging is harmless, and existing literature and papers point out the danger[27].

In terms of health risks, according to 3 studies, DPRs can induce genotoxic effects in oral epithelial cells. These studies show that the frequency of micronuclei increases post exposure in DPR. It has been reported, that Micronucleus test is a rapid assay for chromosomal damage which measures accurate X-ray induced chromosomal damage[14].

In fact, an increase in micronuclei frequency in buccal epithelial cells can increase chromosomal damage and induce apoptosis[21].

Tow studies were show that DPR can even induce cytotoxic effects leading to cell death.

In tow studies, the overall risk of cancer from radiaon in women are higher than men (The mean of The risk of exposure-induced cancer death (REID) values in panoramic radiography were 2.1 per ten million for male patients and 2.41 per ten million for female patients)

It was children was more than adult(The mean of REID (The risk of exposure-induced cancer death) values in panoramic radiography were 7.32 per ten million for children and 2.1 per ten million for adult. The REID values will help dentists to justify the requesting of the DPR[15].

According to studies, it is necessary to avoid or reduce exposure to radiation dose to patients as much as possible[27]. Indeed, when using panoramic radiography, clinicians should be aware of the highest effective dose and should decide whether this type of radiography is warranted [13]. Furthermore, the establishment of Diagnostic Reference Level (DRL) for panoramic and limitation the examination to the area of interest by using collimation feature of panoramic imaging have been strongly recommended [20], [9,17] .

Thus, DPRs should be prescribed at a later stage and after a complete and appropriate clinical dental examination taking into account the patient's symptoms as well as their medical, dental and social history to ensure maximum benefit and adhere to ALARA (As Low As Reasonably Acheivable) principle [21], [28][30]

Table4. Recommendations to reduce radiation doses and risks from DPR according to studies

\begin{tabular}{|c|c|c|}
\hline Recommendations & $\begin{array}{l}\text { Author } \\
\text { (year) }\end{array}$ & Country \\
\hline $\begin{array}{l}\text { When using panoramic } \\
\text { radiography, clinicians should } \\
\text { be aware of the highest effective } \\
\text { dose and justify this type of } \\
\text { radiography }\end{array}$ & $\begin{array}{l}\text { Granlund } \\
\text { and al. } \\
(2016)[13]\end{array}$ & Sweden \\
\hline $\begin{array}{l}\text { The establishment of Diagnostic } \\
\text { Reference Level (DRL) for } \\
\text { panoramic in parotid glands }\end{array}$ & $\begin{array}{l}\text { Toossi and } \\
\text { al. } \\
(2012)[20]\end{array}$ & Iran \\
\hline $\begin{array}{l}\text { Limit examination to the area } \\
\text { of interest (collimation feature) }\end{array}$ & $\begin{array}{l}\text { Benchimol } \\
\text { and al. } \\
(2018)[9] \\
\text { Lee and } \\
\text { al. } \\
(2019)[17]\end{array}$ & Taiwan \\
\hline $\begin{array}{l}\text { The average risk of cancer from } \\
\text { panoramic radiography should } \\
\text { be considered as a guide to }\end{array}$ & $\begin{array}{l}\text { Chaparian } \\
\text { and al. } \\
(2017)[15]\end{array}$ & Iran \\
\hline
\end{tabular}
assess the risks and the benefits for each age group

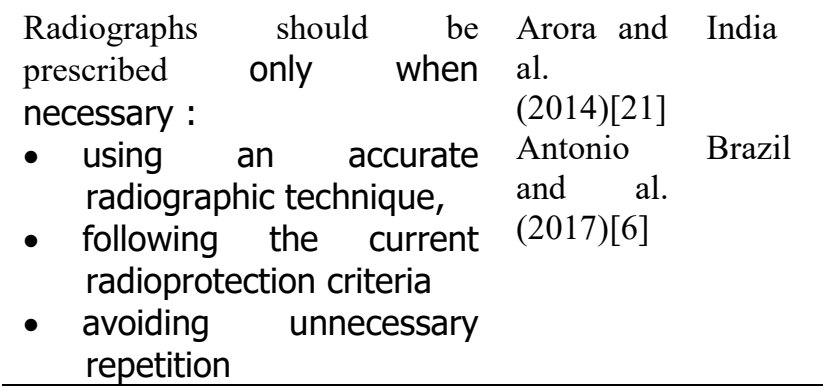

\section{Conclusion}

The aim of this review was evaluated studies that evaluated the radiation risks and doses from dental panoramic radiography (DPR) based on published studies. This review showed that due to the widespread use of DPR and since it entails a radiation risks, the 
protection of patients from x-rays is important. Thus, DPRs should be indicated when necessary, using an accurate radiographic technique and following the current radioprotection criteria, in order to avoid unnecessary repetition.

\section{References}

[1] J. Iannucci et L. J. Howerton, Dental Radiography - E-Book: Principles and Techniques. 2013.

[2] F. Testa et al., "Orthopantomography in pediatric age: a preliminary dosimetric and epidemiologic assessment », ECR 2015 EPOS, mars 04, 2015. https:/epos.myesr.org/poster/esr/ecr2015/C-1781 (consulté le juin 14, 2021).

[3] F. Nasrepour, V. Karami, et M. Gholami, « An Estimate of Radiation Dose to the Lens of the Eyes, Parotid Gland, and Thyroid Gland in Dental Panoramic Radiography », Iran. J. Med. Phys., vol. 16, $\mathrm{n}^{\mathrm{o}}$ 6, p. 425-429, nov. 2019, doi: 10.22038/ijmp.2019.35929.1454.

[4] E. Pakbaznejad Esmaeili, M. Ekholm, J. Haukka, M. Evälahti, et J. Waltimo-Sirén, « Are children's dental panoramic tomographs and lateral cephalometric radiographs sufficiently optimized? », Eur. J. Orthod., vol. 38, n ${ }^{\circ}$ 1, p. 103-110, févr. 2016, doi: 10.1093/ejo/cjv076.

[5] P. E. Elmira, «Justification and optimization of dental panoramic tomography and lateral cephalometric radiography among Finnish children $»$, p. 72.

[6] E. L. Antonio, A. J. do Nascimento, A. A. S. de Lima, M. S. S. Leonart, et Â. Fernandes, genotoxicity and cytotoxicity of $x$-rays in children exposed to panoramic radiography, Rev. Paul. Pediatr., vol. 35, $\mathrm{n}^{\mathrm{0}}$ 3, p. 296-301, 2017, doi: 10.1590/1984-0462/;2017;35;3;00010.

[7] E. M. M. Cerqueira et al., « Genotoxic effects of X-rays on keratinized mucosa cells during panoramic dental radiography ", Dentomaxillofacial Radiol., vol. 37, $\mathrm{n}^{\mathrm{0}} 7$, $\mathrm{p}$. 398-403, oct. 2008, doi: 10.1259/dmfr/56848097.

[8] V. E. Rushton, K. Horner, et H. V. Worthington, «Screening panoramic radiology of adults in general dental practice: radiological findings », $\mathrm{Br}$. Dent. J., n ${ }^{\circ}$ 9, p. 7, 2001.

[9] D. Benchimol, J. Koivisto, N. Kadesjö, et X.-Q. Shi, «Effective dose reduction using collimation function in digital panoramic radiography and possible clinical implications in dentistry ", Dentomaxillofacial Radiol, vol. 47, $\mathrm{n}^{\mathrm{0}} 7$, $\mathrm{p}$. 20180007, oct. 2018, doi: 10.1259/dmfr.20180007.

[10] «Orthodontic radiographs. Guidelines, 3rd edition (2008) | European Journal of Orthodontics | Oxford Academic $»$. https://academic.oup.com/ejo/article/30/6/669/500 629 (consulté le juin 14, 2021).

[11] V. E. Rushton, K. Horner, et H. V. Worthington, «Aspects of panoramic radiography in general dental practice », Br. Dent. J., vol. 186, n 7, p. 3, 1999.

[12] E. Pakbaznejad Esmaeili, M. Ekholm, J. Haukka, et J. Waltimo-Sirén, «Quality assessment of orthodontic radiography in children », Eur. J. Orthod., vol. 38, n ${ }^{\circ}$ 1, p. 96-102, févr. 2016, doi: 10.1093/ejo/cjv033.

[13] C. Granlund, A. Thilander-Klang, B. Ylhan, S. Lofthag-Hansen, et A. Ekestubbe, «Absorbed organ and effective doses from digital intra-oral and panoramic radiography applying the ICRP 103 recommendations for effective dose estimations », Br. J. Radiol., vol. 89, $\mathrm{n}^{\circ} 1066$, p. 20151052, oct. 2016, doi: 10.1259/bjr.20151052.

[14] A. Pai, R. C. Sharma, R. M. Naik, et Y. Guruprasad, «Biomonitoring of genotoxic and cytotoxic effects of gingival epithelial cells exposed to digital panoramic radiography $», J$. Orofac. Sci., vol. 4, no 2, p. 124, janv. 2012, doi: 10.4103/0975-8844.106207.

[15] A. Chaparian, «Evaluation of radiation-induced cancer risk to patients undergoing intra-oral and panoramic dental radiographies using experimental measurements and Monte Carlo calculations ", Iran. J. Radiat. Res. IJRR, vol. 15, p. 197-205, avr. 2017, doi: 10.18869/acadpub.ijrr.15.2.197.

[16] W. Qiang, F. Qiang, L. Lin, Estimation of effective dose of dental $x$-ray devices, Radiation Protection Dosimetry, Oxford Academic. (2019)

[17] C. Lee et al., «Efficacy of the Monte Carlo method and dose reduction strategies in paediatric panoramic radiography », Sci. Rep., vol. 9, n ${ }^{\circ}$ 1, p. 9691, déc. 2019, doi: 10.1038/s41598-019-461570 .

[18] G. E. Campillo-Rivera, J. Vázquez-Bañuelos, Á. García-Duran, M. I. Escalona-Llaguno, M. V. Arteaga, et H. R. Vega-Carrillo, « Doses in eye lens, thyroid, salivary glands, mammary glands, and gonads, due to radiation scattered in dental orthopantomography », Appl. Radiat. Isot., vol. 146, p. 57-60, avr. 2019, doi: 10.1016/j.apradiso.2019.01.022.

[19] E. Moudi, « Assessment of Radiation Exposure of Head and Neck during Panoramic Radiography in Different Age Groups », Sci. J. Clin. Med., vol. 3, $\mathrm{n}^{\mathrm{o}} 1, \mathrm{p} .10$.

[20] M. T. B. Toossi, F. Akbari, et S. B. Roodi, «Radiation Exposure to Critical Organs in Panoramic Dental Examination », Acta Med. Iran., p. 809-813, 2012.

[21] P. Arora, P. Devi, et S. S. Wazir, « Evaluation of Genotoxicity in Patients Subjected to Panoramic Radiography by Micronucleus Assay on Epithelial Cells of the Oral Mucosa », J. Dent. Tehran Iran, vol. 11, no 1, p. 47-55, janv. 2014.

[22] N. Preethi, N. Chikkanarasaiah, et S. S. Bethur, "Genotoxic effects of X-rays in buccal mucosal cells in children subjected to dental radiographs $»$, BDJ Open, vol. 2, n ${ }^{\circ} 1$, p. 16001, déc. 2016, doi: 10.1038/bdjopen.2016.1. 
[23] M. Waingade et R. S. Medikeri, "Analysis of micronuclei in buccal epithelial cells in patients subjected to panoramic radiography », Indian $J$. Dent. Res., vol. 23, $\mathrm{n}^{\circ}$ 5, p. 574, janv. 2012, doi: 10.4103/0970-9290.107329.

[24] M. C. Lin et al., «Dental diagnostic X-ray exposure and risk of benign and malignant brain tumors », Ann. Oncol., vol. 24, n 6, p. 1675-1679, juin 2013, doi: 10.1093/annonc/mdt016.

[25] K. Horner, « Radiographic selection criteria: new guidelines, old challenges », Br. Dent. J., vol. 214, $\mathrm{n}^{\mathrm{o}}$ 4, p. 201-203, févr. 2013, doi: 10.1038/sj.bdj.2013.158.

[26] E. Pakbaznejad Esmaeili, J. Waltimo-Sirén, T. Laatikainen, J. Haukka, et M. Ekholm, «Application of segmented dental panoramic tomography among children: positive effect of continuing education in radiation protection ", Dentomaxillofacial Radiol., vol. 45, $\mathrm{n}^{\circ}$ 6, $\mathrm{p}$. 20160104, juill. 2016, doi: 10.1259/dmfr.20160104.

[27] «Kweon, Dae-Cheol, et al. "A literature review and analysis of dosimetry in panoramic radiography." Journal of radiological science and technology 33.1 (2010): 1-10 ». Consulté le: juin 14, 2021. [En ligne]. Disponible sur: https://www.koreascience.or.kr/article/JAKO2010 19451500247.pdf

[28] R. J. Kratz, J. N. Walton, M. I. MacEntee, C. T. Nguyen, et D. MacDonald, «Panoramic radiographs made before complete removable dental prostheses fabrication: A retrospective study of clinical significance », J. Prosthet. Dent., vol. $118, \mathrm{n}^{\circ} 1$, p. 26-30, juill. 2017, doi: 10.1016/j.prosdent.2016.09.034.

[29] M. A. Moll et al., "Comparison of clinical and dental panoramic findings: a practice-based crossover study », BMC Oral Health, vol. 13, $\mathrm{n}^{\circ} 1$, p. 48, déc. 2013, doi: 10.1186/1472-6831-13-48.

[30] M. N. Rushton et V. E. Rushton, «A study to determine the added value of 740 screening panoramic radiographs compared to intraoral radiography in the management of adult $(>18$ years) dentate patients in a primary care setting ", J. Dent., vol. 40, n ${ }^{\circ}$ 8, p. 661-669, août 2012, doi: 10.1016/j.jdent.2012.04.018. 